\title{
EFFECT OF AIR SPEED \\ AND SIZE VENT AREA ON THE PRECOOLING CYCLE FOR CANTALOUPE FRUITS
}

\author{
M. A. Rashwan *
}

ABSTRACT

Cantaloupe is one of the important crops in Egypt a long time ago. Now a day there is a high increase in cantaloupe's production especially in the new reclaimed areas. Large amount of production is exported to international markets which represents a good income and a new source for hard currency. Removing heat from the product is required to prevent fruits deterioration and loss of its value. Forced-air cooling is considered an improved technique compared with other cooling methods such as room cooling since the cold air is forced through produce packed in boxes or ballet bins via its venting areas. In the present work, the fruits were analyzed for physiological properties such as loss in weight as well as the ostensibly properties. Three ranges of air speed were used: 2.5, 3.75 and $5 \mathrm{~m} / \mathrm{s}$ and two sidewall vent area: $5 \%, 10 \%$ to examine the effect of increasing air speed and sidewall vent area on the precooling cycle and weight loss for cantaloupe fruits. The results indicated that, the air flow rate, total opening area and opening size show a significant effect on cooling efficiency and the quality of the cantaloupes fruits. Cooling temperature can extend the period of fresh appearance of the product, also increasing air flow rate and increasing side wall vent area has a good effect on the quality of the fruits.

\section{INTRODUCTION}

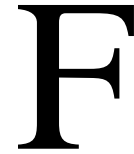
Truits and vegetables begin to deteriorate after they are harvested and separated from their growing environment. To preserve the quality of fruits and vegetables and maximize profits for growers, it is critical to control the temperature of fresh produce and minimize the amount of time that products are exposed to detrimental temperatures. Precooling constitutes is the first link in the cold chain for food products. Of the various precooling techniques, air cooling is the most commonly adopted one (Abdul Majeed, et al., 1980).

*Assist. Prof. Agric. and Biosystems Eng. Dept., Fac. of Agric. (ElAlexandria University. Egypt.

Shatby), 
Pankaj et al. (2012) indicated that the temperature is one of the most important factors affecting the postharvest life of fruit as it influences to a large extent the physiological and biological changes taking place after harvest. Elansari (2009) indicated that, forced-air cooling is an improved technique compared by other methods, since the cold air is forced through produce packed boxes or pallet bins via its venting areas. He also added that, the way of packaging and the packaging materials should be properly selected to avoid any blockage of air passage and allow good air flow to achieve the cooling rate desired. Tator and Elansari (1998) showed that, forced-air cooling is considered as an industrial process which operates under significantly sever conditions. Abdul Majeed, et al. (1980) presented an analysis of the cooling characteristics of food products in air. They showed the coupled effects of heat and moisture transfer at the surface are included and the one-dimensional heat conduction equation in rectangular, spherical and cylindrical coordinates is solved. Wijewardane et al. (2009) have reported that, a number of researchers have made attempts to enhance the storage life of the cantaloupe using different substances at the pre or postharvest stages. Abdul Majeed et al. (1980) indicated that, the transient cooling of food products in refrigerated air is complicated due to the accompanying moisture transfer from the product surface. This surface moisture can be either due to the usual washing treatments or as a result of the inherent loss of free water from within the product. Kaynas and Sivritepe (1995) indicated that, the temperature of the produce is proportional to the deterioration by decay and senescence and consequently, to the potential storage life. Pre-cooling facilities good temperature management for prevention of ripening and effectively delaying the set of senescence. Besides growth of most disease organisms and their spread is greatly reduced at lower temperatures. Thus, maintenance of low product temperature is essential in reducing water loss and subsequent product shriveling. Robbins and Patrick (1992) indicated that, the fruits were exposed to 5, 10 and $20{ }^{\circ} \mathrm{C}$ for 45 days and then kept at ambient temperature for 25 days. The results indicated that, disease incidence and prevalence of Penecillium digitatum were higher in fruits stored at 5 and $20{ }^{\circ} \mathrm{C}$ and were lower at $10{ }^{\circ} \mathrm{C}$. Weight loss was higher in the fruits stored 
at $20{ }^{\circ} \mathrm{C}$ followed by $5{ }^{\circ} \mathrm{C}$ and was lower at $10^{\circ} \mathrm{C}$. The effect of delayed pre-cooling on fresh red raspberry fruit during storage was determined. They reported that, pre-cooling was delayed for 0.5 to 12 hour, followed by cold storage for 8 days, with subsequent storage at $20{ }^{\circ} \mathrm{C}$ for 24 hour. Weight loss was greater with increasing delays of precooling. Robbins and Patrick (1992) indicated that, in 1989, weight loss during the delay increased linearly with increasing delay for all cultivars. This was a result of more hours at the higher temperature and in a greater percentage of weight loss per hour with increasing delay. This differs from the results of (Robinson et al., 1975) who reported weight loss was more rapid immediately after harvest, with the rate falling to a fairly steady value for fruit stored at a constant temperature. The weight loss in citrus fruits was significantly affected by storage temperature. It increased with increase in post-storage incubation at ambient temperature. Abdur rab et al. (2012) referred that, the weight loss significantly increased from $1.039 \%$ to $8.014 \%$ with each 5 days interval from 0 to 25 days post storage incubation. Kader and Saltveit (2003) indicated that, the optimum temperature to store cantaloupe is ranged between 2 and $7{ }^{\circ} \mathrm{C}$. Kader (2002) indicated that, boxes should have about 5\% sidewall vent area to accommodate airflow without excessive pressure drop across the box. Mitchell, et al. (1972) indicated that, the recommended pattern of vents for box cartons used to hold produce that is to be forced-air cooled should make up $5 \%$ of the total surface area, and should be located 5 to $7.5 \mathrm{~cm}$ away from the corners. A few large vents $(1.3 \mathrm{~cm}$ wide or more) are better than many small vents.

Abdul Majeed, et al. (1980) indicated that, most of the analysis does not take into account the effect of moisture transfer during cooling. However, a few attempts have been made to account for the combined heat and mass transfer during the process. Trevor et al. (1997) indicated that, cantaloupes are harvested by maturity and not by size. Commercial maturity is ideally at the firm-ripe stage or "3/4 to full-slip". Cantaloupes ripen after harvest but not increase in sugar content. Cultivars vary in their external color at this stage of maturity and may retain a greenish cast. This skin color typically transitions from gray to dull green when immature, deep uniform green at maturity, and light yellow at full 
ripeness. Raised and well-rounded netting on the fruit surface is another indicator of proper commercial maturity. He also added that, the essential thing is that the crates be sufficiently open so that the cooling fluid comes in contact with the entire surface of the cantaloupe.

In the present work, the fruits were analyzed for physiological and ostensibly properties. The effect of increasing air speed flow rate and sidewall vent area on the precooling cycle and weight loss of cantaloupe fruits were examined.

\section{MATERIALS AND METHODS}

To study the influent of changing air speed flow rate and side vent area on cantaloupe fruits, an experiment was carried out at Alex post-harvest laboratory, faculty of Agriculture, Alexandria University. The cantaloupe fruits, which used in the experiment, were approximately similar size (10$12 \mathrm{~cm}$ diameter) and maturity. The experimental room has a fixed temperature of $6^{\circ} \mathrm{C}$, and $\mathrm{RH}$ of $85-90 \%$, the ambient temperature outside was ranged between 25 and $27^{\circ} \mathrm{C}$ during 6 days of experiments.

\section{Cooling system:}

The system consists of two parts: cooling box and centrifugal fan and all parts were put inside a refrigeration room $(2 \mathrm{~m} \times 1.80 \mathrm{~m})$ which was adjusted at $6^{\circ} \mathrm{C}$. This cooling temperature agreed with the optimum temperature to store cantaloupe (Kader and Saltveit, 2003).

\section{Cooling box:}

The cooling box (Figure 1, 2) made of wood with $40 \mathrm{~cm} \times 30 \mathrm{~cm} \times 25$ $\mathrm{cm}$ and the side wall can be changed with $5 \%$ or $10 \%$ sidewall vent area as agreed with (Kader, 2002). The box connected with an air flow rate fan through a metal part. Packed produce with airflow restricting materials should be taken in consideration when sizing the system air flow and static head pressure of the fans.

\section{Centrifugal fan:}

A centrifugal fan (power 1/2 hp.) was used in the experiment to provide the cooling box with cold air. The quantity of air flow was determined by using a flow-rate tap which adjusts to give $1 / 2,3 / 4$ and full quantity of air or $2.5,3.75$ and $5 \mathrm{~m} / \mathrm{sec}$. 


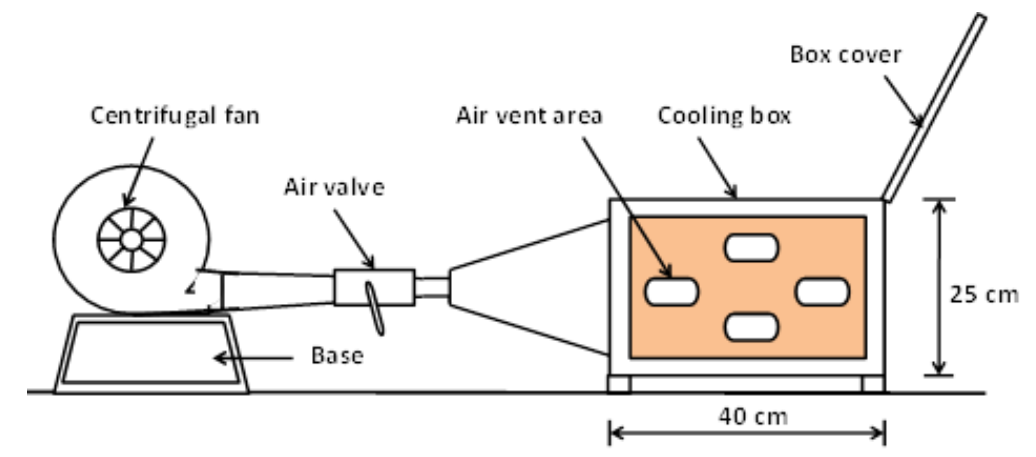

Fig. 1 Schematic diagram of the cooling box and centrifugal fan

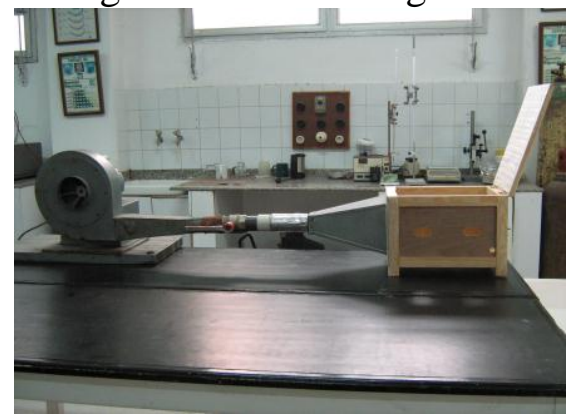

Fig. 2. A photo of the cooling system

\section{Temperature measurements:}

The temperature of fruits was automatically measured daily for 5 hours by using a data logger DL2 version 5.0, Data-T Devices Cambridge-England as shown in Figure (3). PC software Ls2Win was first used to program the logger. Sensors probe (Copper-Constantan wire) were inserted under surface and near the center of fruit to measure its surface and center temperature. On the other side the logger was connected with computer to save and record data. After 5 hours, the fruits get out from the cooling box and ostensibly examined and weighted.
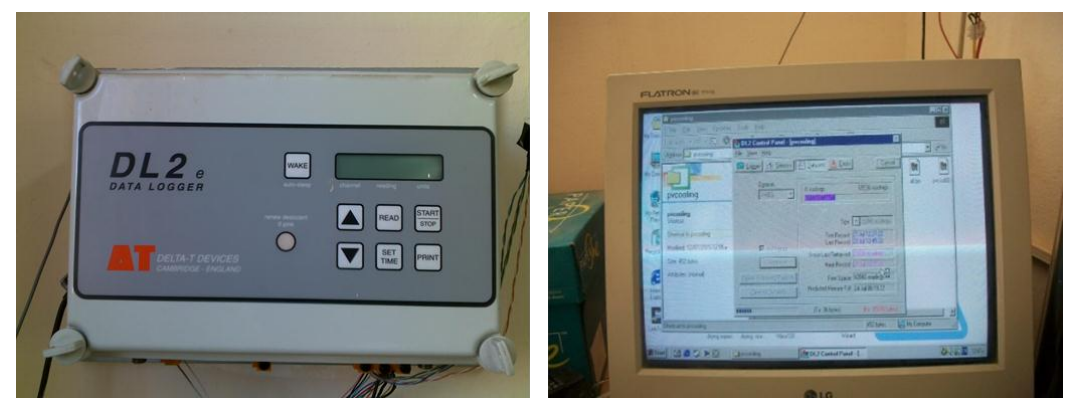

Fig. 3. Data logger DL2 version 5.0 connect with PC 


\section{Air speed:}

The speed of the air rate passing through the cooling box was measured by using an air velocity meter, (Tri-Sence Model No. 37000-00, ColeParmer Instrument Co.) as shown in Figure (4).

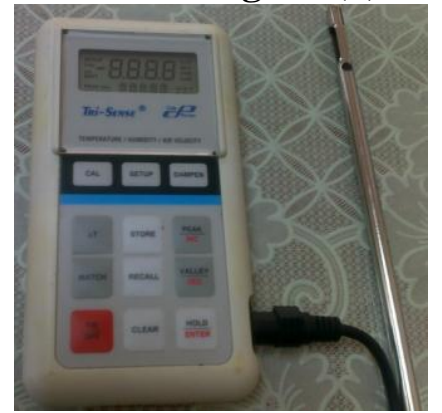

Fig. 4. Air velocity meter and its probe.

\section{Statistical analysis:}

The experiments were carried out using analysis of variance appropriate for RCB with three replicates. Each replicate consisted of 6 fruits. Means were separated using Least Significant Difference (LSD) at 5\% level of probability when the F-values were significant (SAS version 9.1.3 portable).

\section{RESULT AND DISSCUSION}

It's important to mention that, the heat inside the product have to be remove from the product to prevent fruits deterioration. The amount of heat to be removed depends on the produce and the required storage temperatures. Proper design fast cooling temperature and relative humidity control in cooling environment can extend the period of fresh appearance of the product. The results of the experiments are given in Figure (2) and Tables $(\mathbf{1}, \mathbf{2}, \mathbf{3})$ as a function of precooling treatments and air flow-rate levels and sidewall vent area.

Tables (1) shows that: the percentage of weight loss (WL, \%) ranged between 0.079 to $0.179 \%$ at air speed (AS) of $2.5 \mathrm{~m} / \mathrm{s}$, and at side vent area (SVA) of $10 \%$, however, the percentage of WL ranged between 0.079 to $0.22 \%$ at $\mathbf{A S}$ of $2.5 \mathrm{~m} / \mathrm{s}$, and at SVA of $10 \%$.

Table (2) shows that: the percentage of WL, \% ranged between 0.134 to $0.270 \%$ at $\mathbf{A S}$ of $3.75 \mathrm{~m} / \mathrm{s}$, and at SVA of $10 \%$, however, the percentage of WL ranged between 0.090 to $0.186 \%$ at $\mathbf{A S}$ of $2.5 \mathrm{~m} / \mathrm{s}$, and at $\mathbf{S V A}$ of $10 \%$. 
Table (3) shows that: the percentage of WL, ranged between 0.271 to $0.426 \%$ at $\mathbf{A S}$ of $5 \mathrm{~m} / \mathrm{s}$, and at SVA of $10 \%$, however, the percentage of WL ranged between 0.22 to $0.268 \%$, at $\mathbf{A S}$ of $5 \mathrm{~m} / \mathrm{s}$, and at SVA of $10 \%$.

Table 1. The percentage of WL of cantaloupe fruits at (AS) of $2.5 \mathrm{~m} / \mathrm{s}$ and SVA of $10 \%$ and $5 \%$

\begin{tabular}{|c|c|c|c|}
\hline \multirow[b]{2}{*}{$\begin{array}{c}\text { No. } \\
\text { of } \\
\text { fruit }\end{array}$} & \multicolumn{3}{|c|}{$(\mathrm{AS}) 2.5 \mathrm{~m} / \mathrm{s}$ and $(\mathrm{SVA}) 10 \%$} \\
\hline & $\begin{array}{l}\text { Weight } \\
\text { before } \\
\text { cooling, g }\end{array}$ & $\begin{array}{l}\text { Weight } \\
\text { after } \\
\text { cooling, g }\end{array}$ & WL,\% \\
\hline 1 & 734.1 & 733.0 & 0.150 \\
\hline 2 & 698.9 & 697.8 & 0.157 \\
\hline 3 & 672.0 & 670.8 & 0.179 \\
\hline 4 & 658.6 & 657.8 & 0.121 \\
\hline 5 & 631.4 & 630.9 & 0.079 \\
\hline 6 & 606.9 & 605.9 & 0.165 \\
\hline
\end{tabular}

\begin{tabular}{ccc}
\hline \multicolumn{3}{c}{$(\mathrm{AS}) 2.5 \mathrm{~m} / \mathrm{s}$ and (SVA) $5 \%$} \\
\hline $\begin{array}{c}\text { Weight } \\
\text { before }\end{array}$ & $\begin{array}{c}\text { Weight } \\
\text { after } \\
\text { cooling, } \mathrm{g}\end{array}$ & $\begin{array}{c}\text { WL,\% } \\
\text { cooling, g }\end{array}$ \\
\hline 863.8 & 861.9 & 0.220 \\
777.0 & 776.3 & 0.090 \\
769.4 & 768.3 & 0.143 \\
758.2 & 757.6 & 0.079 \\
750.3 & 748.9 & 0.187 \\
744.5 & 743.5 & 0.134 \\
\hline
\end{tabular}

Table 2. The percentage of WL of cantaloupe fruits at (AS) of $3.75 \mathrm{~m} / \mathrm{s}$ and SVA of $10 \%$ and $5 \%$

\begin{tabular}{cccc}
\hline & \multicolumn{3}{c}{ (AS) 3.75 m/s and (SVA) $10 \%$} \\
\cline { 2 - 4 } $\begin{array}{c}\text { No. } \\
\text { of } \\
\text { fruit }\end{array}$ & $\begin{array}{c}\text { Weight } \\
\text { before } \\
\text { cooling, } \\
\text { g }\end{array}$ & $\begin{array}{c}\text { Weight } \\
\text { after } \\
\text { cooling, }\end{array}$ & WL,\% \\
\hline 1 & 810.7 & 809.1 & 0.197 \\
2 & 740.6 & 739.1 & 0.203 \\
3 & 741.5 & 739.5 & 0.270 \\
4 & 735.7 & 734.2 & 0.204 \\
5 & 673.2 & 672.3 & 0.134 \\
6 & 664.5 & 663.2 & 0.196 \\
\hline
\end{tabular}

\begin{tabular}{ccc}
\hline \multicolumn{3}{c}{ (AS) $3.75 \mathrm{~m} / \mathrm{s}$ and (SVA) $5 \%$} \\
\hline $\begin{array}{c}\text { Weight } \\
\text { before }\end{array}$ & $\begin{array}{c}\text { Weight } \\
\text { after } \\
\text { cooling, } \mathrm{g}\end{array}$ & $\mathrm{WL}, \%$ \\
& cooling, $\mathrm{g}$ & \\
\hline 1134.1 & 1132.4 & 0.150 \\
971.0 & 969.8 & 0.124 \\
965.2 & 963.4 & 0.186 \\
903.7 & 902.6 & 0.122 \\
887.0 & 886.2 & 0.090 \\
876.7 & 875.8 & 0.103 \\
\hline
\end{tabular}

Table 3. The percentage of WL of cantaloupe fruits at (AS) of $5 \mathrm{~m} / \mathrm{s}$ and SVA of $10 \%$ and $5 \%$

\begin{tabular}{|c|c|c|c|c|c|c|}
\hline \multirow[b]{2}{*}{$\begin{array}{l}\text { No. } \\
\text { of } \\
\text { fruit }\end{array}$} & \multicolumn{3}{|c|}{$(\mathrm{AS}) 5 \mathrm{~m} / \mathrm{s}$ and $(\mathrm{SVA}) 10 \%$} & \multicolumn{3}{|c|}{ (AS) $5 \mathrm{~m} / \mathrm{s}$ and (SVA) $5 \%$} \\
\hline & $\begin{array}{c}\text { Weight } \\
\text { before } \\
\text { cooling, } \mathrm{g}\end{array}$ & $\begin{array}{c}\text { Weight } \\
\text { after } \\
\text { cooling, g } \\
\end{array}$ & $\mathrm{WL}, \%$ & $\begin{array}{l}\text { Weight } \\
\text { before } \\
\text { cooling, g }\end{array}$ & $\begin{array}{c}\text { Weight } \\
\text { After } \\
\text { cooling, g } \\
\end{array}$ & $\overline{W L}, \%$ \\
\hline 1 & 756.8 & 754.2 & 0.344 & 782.7 & 780.6 & 0.268 \\
\hline 2 & 718.5 & 716.1 & 0.334 & 731.9 & 730.2 & 0.232 \\
\hline 3 & 712.9 & 710.6 & 0.323 & 725.8 & 724.2 & 0.220 \\
\hline 4 & 680.9 & 678.0 & 0.426 & 675.6 & 674.1 & 0.222 \\
\hline 5 & 665.2 & 663.4 & 0.271 & 643.0 & 641.4 & 0.249 \\
\hline 6 & 652.0 & 650.1 & 0.291 & 634.6 & 632.9 & 0.268 \\
\hline
\end{tabular}

Table (4) gives a conclusion of the weight loss percentage and the average at various values of air speed and side vent area. 
Table 4. The percentage of weight loss fruits at various air speed and sidewall vent area

\begin{tabular}{lcc}
\hline Air speed and sidewall vent area & Weight loss, \% & Average, \% \\
\hline $2.5 \mathrm{~m} / \mathrm{s}$ and 10\% sidewall vent area & $0.079 \sim 0.179$ & 0.129 \\
$2.5 \mathrm{~m} / \mathrm{s}$ and 5\% sidewall vent area & $0.079 \sim 0.220$ & 0.150 \\
$3.75 \mathrm{~m} / \mathrm{s}$ and 10\% sidewall vent area & $0.134 \sim 0.270$ & 0.202 \\
$3.75 \mathrm{~m} / \mathrm{s}$ and 5\% sidewall vent area & $0.090 \sim 0.186$ & 0.138 \\
$5 \mathrm{~m} / \mathrm{s}$ and 10\% sidewall vent area & $0.271 \sim 0.426$ & 0.349 \\
$5 \mathrm{~m} / \mathrm{s}$ and 5\% sidewall vent area & $0.220 \sim 0.268$ & 0.244 \\
\hline
\end{tabular}

The previous data indicated that, cooling temperature is important to extend the period of fresh appearance of the cantaloupe fruits. It assists in maintaining quality by reducing the rate of metabolic activities such as respiration, transpiration. Also increasing cooling air speed or increasing air flow rate does not effect the quality and ostensibly properties probable due to hard skin of the fruits and/or the cooling temperature was not very low although many researchers reported that, plants of tropical and subtropical origin, and some tissues from plants of temperate origin are injured by exposure to non-freezing temperature below $12^{\circ} \mathrm{C}$ (Bramlage 1982, Couey 1982, Lyons 1973, Saltveit and Morris 1990). Alexander

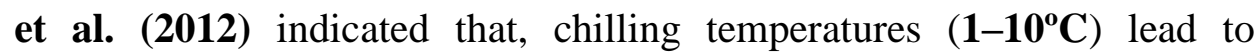
numerous physiological disturbances in the cells of chilling-sensitive plants and result in chilling injury and death of tropical and subtropical plants.

The weight loss can be calculated as percent of original weight. For this purpose initial and final weight of the fruits was determined at time zero and after storage inside the refrigerator with the help of an electronic balance. The percentage of weight loss was calculated using the following formula (Abdur Rab et al. 2012):

$$
\text { Weight loss }(\%)=\frac{\text { Weightof fresh fruit }- \text { Weightafter interval }}{\text { Weightof fresh fruit }} \times 100
$$

Rapid cooling of the produce to safe storage or transportation temperature is imperative in preservation of quality and increase the shelf life by arresting the deteriorative changes caused by physiological and pathological agencies. The harvested produce contains substantial amount of heat associated with the product temperature and is known as 
field heat, a significant part of cooling load. Precooling is the rapid extraction of heat from the product before transport, storage, and processing. Depending on the temperature, the product will lose its quality in no time unless promptly and appropriately cooled.

\section{Temperature ratio $\left(T_{\mathrm{r}}\right)$ :}

Temperature data of cantaloupe fruits were plotted on graphs for different air speed flow rate and side vent area to find the optimum condition for fast cooling to protect the quality deterioration. The ultimate use of the experimental data for Cantaloupe can be made general by use of the temperature ratio concept. Fast cooling responses for any desired initial cantaloupe temperature can be calculated from experimental data obtained at a different initial product temperature. The temperatures ratio, $\boldsymbol{T}_{\mathbf{r}}$, at any time during the fast cooling of cantaloupe for the set of experiments can be presented by the following formula (Ansari and Afaq, 1986).

$$
T_{r}=\frac{T-T_{0}}{T_{i_{n}}-T_{0}}
$$

Where:

$T=$ Temperature of cantaloupe at both center $\left(T_{\mathrm{c}}\right)$, and surface or under skin $\left(T_{\mathrm{s}}\right)$, for different sizes, ${ }^{\circ} \mathrm{C}$.

$T_{\mathrm{o}}=$ Air refrigeration temperature, ${ }^{\circ} \mathrm{C}$.

$T_{\text {in }}=$ Initial cantaloupe temperature after harvesting, ${ }^{\circ} \mathrm{C}$.

According to the previous formula, Figure (3) shows the relationship between temperature ratio, $\left(T_{\mathrm{r}}\right)$ and cooling time, $(\mathrm{t})$ for three speeds of air $(2.5,3.75$ and $5 \mathrm{~m} / \mathrm{s})$ and for 10 and $5 \%$ side vent area under skin (surface) of the cantaloupe fruits. The graph shows that temperature ratio decrease with increase of cooling time for all speed of air. The surface temperature of cantaloupe has a sharp decrease with increase of air speed in the first one hour of cooling, and after that the temperature slightly decreased during the left four hours, where the average temperature was $\left(6.33,7.27,8.21{ }^{\circ} \mathrm{C}\right)$ at $5,3.75$ and $2.5 \mathrm{~m} / \mathrm{s}$ at $10 \%$ side vent area and was $\left(7.6,8.3,9.73{ }^{\circ} \mathrm{C}\right)$ at $5,3.75$ and $2.5 \mathrm{~m} / \mathrm{s}$ at $5 \%$ side vent area respectively. 

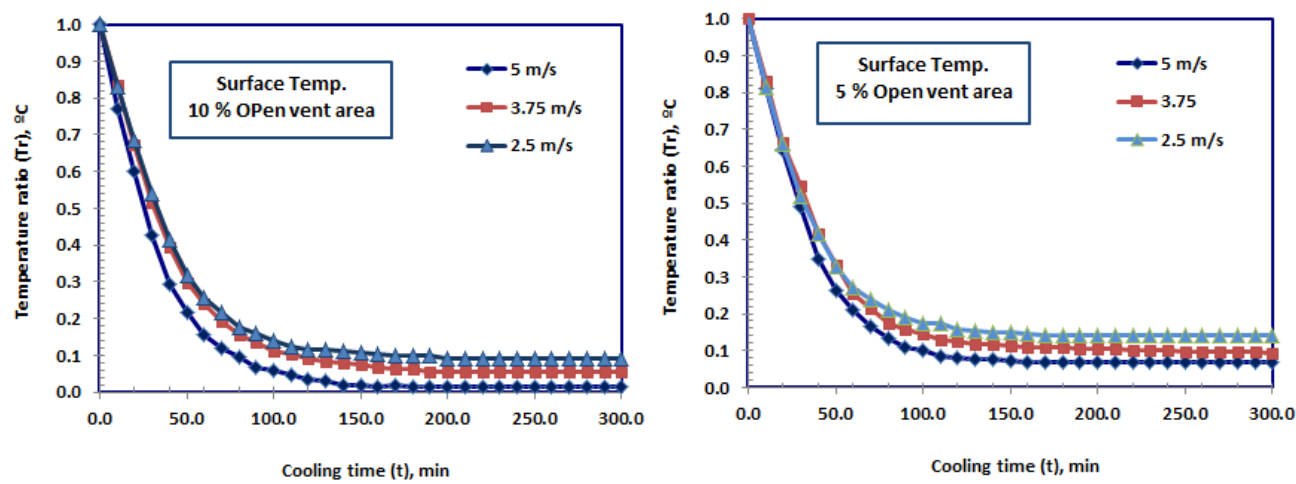

Fig. 3. Temperature ratio of cantaloupe fruit' surface versus cooling time at different air cooling speed and open vent area.

Figure (4) shows the relationship between temperature ratio, $\left(T_{\mathrm{r}}\right)$ and cooling time, (t) for three speeds of air $(2.5,3.75$ and $5 \mathrm{~m} / \mathrm{s})$ and for 10 and 5\% side vent area of the cantaloupe fruits center. The graph shows that temperature ratio decrease with increase of cooling time for all speed of air. The surface temperature of cantaloupe has a sharp decrease with increase of air speed in the first one hour of cooling, and after that the temperature slightly decreased during the left four hours, where the average temperature was $\left(7.9,8.5,9.75^{\circ} \mathrm{C}\right)$ at $5,3.75$ and $2.5 \mathrm{~m} / \mathrm{s}$ at $10 \%$ side vent area and was $\left(8.8,9.26,9.88{ }^{\circ} \mathrm{C}\right)$ at $5,3.75$ and $2.5 \mathrm{~m} / \mathrm{s}$ at $5 \%$ side vent area respectively.
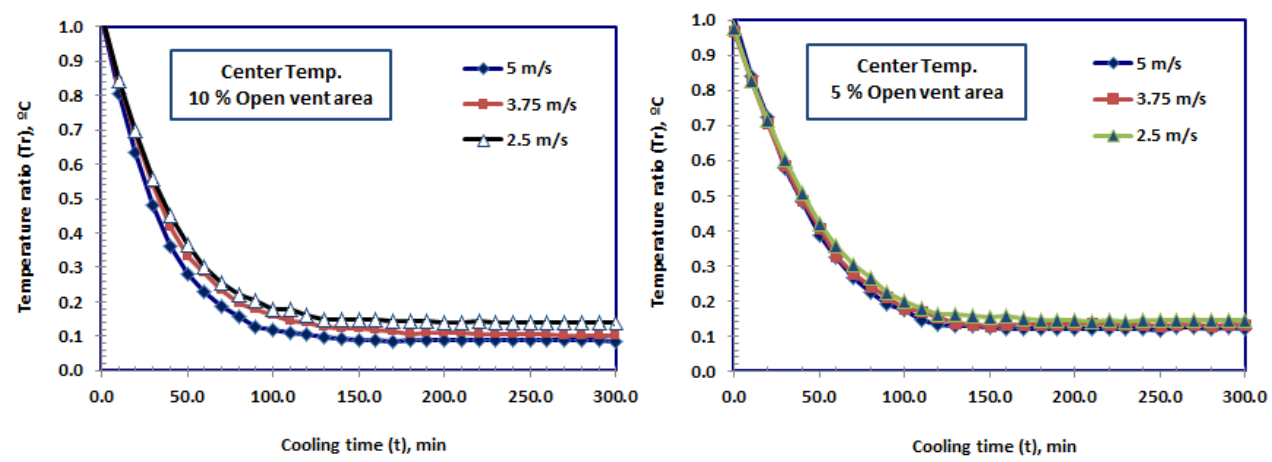

Fig. 4. Temperature ratio of cantaloupe fruit' center versus cooling time at different air cooling speed and open vent area.

The previous figures show the relation chip between temperature and cooling time, cantaloupe temperature's inside cooling box started at about $30{ }^{\circ} \mathrm{C}$ and rabid decreased to become constant at a temperature ranged 
between 6.54 to $9.11^{\circ} \mathrm{C}$ after 3 hours from starting the experiment. Table (5) shows more details of the results.

The trends of the curves in all figures were almost identical, while the weight loss was limited and it ranged between 0.129 to $0.349 \%$ as shown in Table (4). The small of weight loss due to small stored time (5 hours) and maybe some weight loss was occurring after harvesting.

Table 5. Final surface and center temperature of cantaloupe fruits under different air speed and sidewall vent area

\begin{tabular}{lcc}
\hline Air speed and sidewall vent area & $\begin{array}{c}\text { Final surface } \\
\text { Temperature, }{ }^{\mathbf{}} \mathbf{C}\end{array}$ & $\begin{array}{c}\text { Final center } \\
\text { Temperature, }{ }^{\circ} \mathbf{C}\end{array}$ \\
\hline $2.5 \mathrm{~m} / \mathrm{s}$ and 10\% sidewall vent area & 8.203 & 9.753 \\
$2.5 \mathrm{~m} / \mathrm{s}$ and 5\% sidewall vent area & 9.737 & 9.870 \\
$3.75 \mathrm{~m} / \mathrm{s}$ and 10\% sidewall vent area & 7.267 & 8.540 \\
$3.75 \mathrm{~m} / \mathrm{s}$ and 5\% sidewall vent area & 8.190 & 9.260 \\
$5 \mathrm{~m} / \mathrm{s}$ and 10\% sidewall vent area & 6.337 & 8.797 \\
$5 \mathrm{~m} / \mathrm{s}$ and 5\% sidewall vent area & 7.613 & 7.967 \\
\hline
\end{tabular}

\section{Statistical analysis:}

The data were statistically analyzed using analysis of variance appropriate for RCB design and means were compared using LSD test at 5\% level of probability when the F-values were significant (SAS version 9.1.3 portable) and the results are shown below.

Var1 (surface)

\begin{tabular}{llllll}
\hline SOURCE & DF & Anova SS & Mean Square & F Value & Pr $>$ F \\
\hline Time & 10 & 8425.218800 & 842.521880 & 8866.63 & $<0.0001$ \\
Area & 1 & 85.774255 & 85.774255 & 902.68 & $<0.0001$ \\
Speed & 2 & 167.726910 & 83.863455 & 882.57 & $<0.0001$ \\
& \multicolumn{5}{c}{ The ANOVA Procedure } \\
\hline
\end{tabular}

\section{$\underline{\text { Var2 (center) }}$}

\begin{tabular}{llllll}
\hline SOURCE & DF & Anova SS & Mean Square & F Value & Pr $>$ F \\
\hline Time & 10 & 8557.314371 & 855.731437 & 2823.60 & $<0.0001$ \\
Area & 1 & 15.798813 & 15.798813 & 52.13 & $<0.0001$ \\
Speed & 2 & 129.175476 & 64.587738 & 213.12 & $<0.0001$ \\
& \multicolumn{5}{c}{ The ANOVA Procedure } \\
\hline
\end{tabular}


From the previous tables, a significant differences between the means of the independent parameters speed and area.

\section{CONCLUSION}

Forced-air cooling is considered an improved technique compared with other cooling methods such as room cooling since the cold air is forced through produce packed in boxes or ballet bins via its venting areas. The versatility of forced-air coolers that allows for cooling of almost any fruit or vegetable and can function as a precooling unit and a room cooler. The fruits were analyzed for physicochemical and physiological such as loss in weight. In the present work, three ranges of air speed were used: 2.5, 3.75 and $5 \mathrm{~m} / \mathrm{s}$ and sidewall vent area of $5 \%, 10 \%$ to examine the effect of increasing the air speed and sidewall vent area on the weight loss and precooling cycle for cantaloupe fruits. The results indicated that, the weight loss in cantaloupe fruits is slightly affected by air speed and sidewall vent area. The weight loss ranged between 0.129 to $0.349 \%$ during the 5 hours daily.

\section{REFERENCES}

Abdul Majeed, P. M. A., S. S. Murthy, M. V. K. Murthy, 1980. Prediction of Air cooling Characteristics of Moist Food Products, Journal of Transactions of the ASAE 1980 Vol. 23 No. 3 pp. 788 792.

Abdur Rab, S. Muhammad, U. K. Naqib, N. Khalid, A. Muhammad and K.K. Mansoor, 2012. Influence of Storage Temperature on fungal Prevalence and Quality of Citrus Fruit, Khyber Pakhtunkhwa Agricultural University, Peshawar 25130, Pakistan, Pak. J. Bot., 44(2): 831 836.

Alexander S. L., B. Aušra, B. Česlovas and D. Pavelas, 2012. Chilling Injury In Chilling-Sensitive Plants: a review, Žem dir bystė Agriculture, vol. 99, No. 2 (2012), p. 111 124.

Ansari, F. A. and A. A. Faq 1986. Pre-cooling of cylindrical food products, International Journal of Refrigeration, 9(5), 161 163.

Bramlage, W. J. 1982. Chilling Injury of Crops of Temperate Origin,HortScience 17:165 168. 
Couey, H. M, 1982, Chilling Injury of Crops of Tropical and SubTropical Origin. Hort Science 17: 162 165.

Elansari, Atef M., 2009. Design Aspects in the Precooling Process of resh Produce, Frish Produce, 2009 Global Science Books, 49 56.

Kader, A. A. and M. E. Saltveit, 2003. Respiration and gas exchange. In Bartz, J. and Brecht, J., eds. Post-harvest physiology and pathology of vegetables. $2^{\text {nd }}$ edition. Marcel Dekker Inc, New York, NY.

Kader, A.A., 2002. Postharvest Tech. of Horticultural Crops. $3^{\text {rd }}$ edition. Univ. of California, Agric. \& Natural Resources, Publication 3311, $535 \mathrm{p}$.

Kaynas, K. and H. O. Sivritepe, 1995. Effect of Precooling Treatments on storage quality of mature green tomatoes. Acta Hort. 412: 200 209.

Lyons, J., 1973. Chilling injury in plants, Annu, Rev, Plant Physiol, 24: 445 466.

Mitchell, F. G., R. A. Parsons, 1972. Commercial Cooling of Fruits and Vegetables. California Agricultural Experiment Station Extension Service, Manual 43, December, 1972.

Pankaj B. P., U. L. Opara, V. Clement, M. A. Delele, .A.AL-Said, 2012. Design of Packaging Vents for Cooling Fresh Horticultural Produce, Food Bioprocess Tech. (2012) 5:2031 2045.

Robbins J. and P. M. Patrick, 1992. Fruit Quality of Stored, Fresh Red Raspberries After A Delay In Precooling, Hort Tech. Oct./Dec. 2(4).

Robinson, J.E., K.M. Browne, and W.G. Burton, 1975. Storage Characteristics of Some Vegetables and Sot Fruits. Ann. Applied Biol. 81:399 408.

Saltveit, M.E., L.L., Morris, 1990. Overview on Chilling Injury of Horticultural Crops. In: Wang CY (ed) Chilling Injury of Horticultural Crops. CRC Press Inc., Boca Raton, FL, pp 3 15. ISBN 0-8493-5736-5.

Tator, R. and A.M. Elansari, 1998. Fast cooling technical manual. Ministry of Agricultural and reclamation, Egypt. ATUT technical report. Publication No. 50. 
Trevor V.S., M. Cantwell and J. Mitchell, 1997. Honeydew:

Recommendations for Maintaining Postharvest, Quality of

Cantaloupe Department of Plant Sciences, University of California,

Davis.

Wijewardane, R. M. N. A. and S. P. S. Guleria1, 2009. Combined Effects of Precooling, Application of Natural Extracts and Packaging on the Storage Quality of Apple, Royal Delicious, Institute of Postharvest Tech., Research and Development Centre, Jayanthi Mawatha.

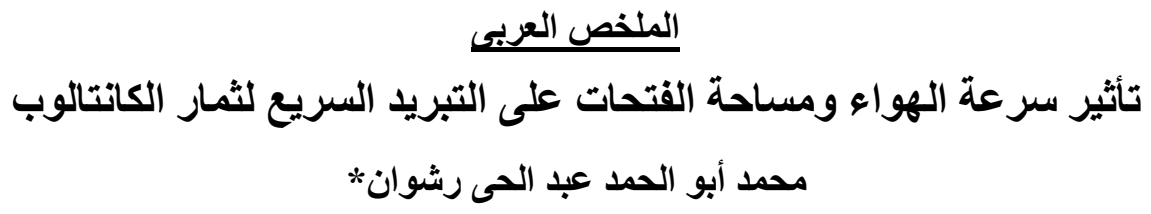

تعتبر المحافظة علي جودة الخضروات والفاكهة من أهم العمليات التي يجب السعي الدائم لها بغرض تقليل الفاقد والتالف منها حيث انها تعتبر مواد حية تستمر بها العمليات الحيوية بعد

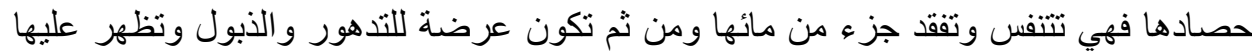
اعر اض الثيخوخة مالم تتوفر لها ظروف تداول ونقل وتعبئة وتخزين و عرض من مناسبة تعمل فئل

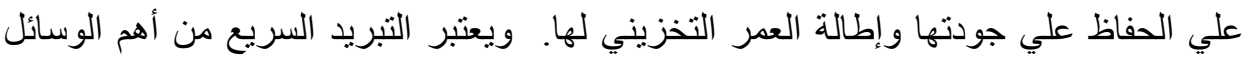

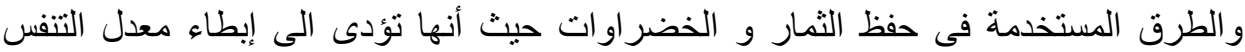
وتقليل فقد الماء من الثمار أثناء النقل والتداول والتخزين كما انها تقلل من نشاط الكائنات الحية

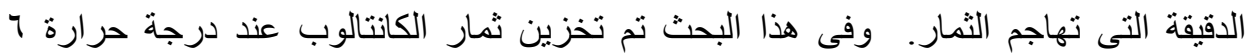

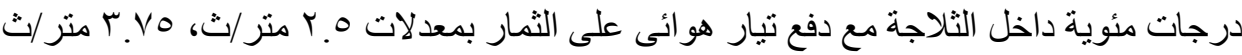

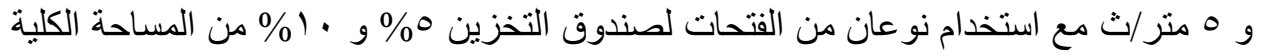
لجانب الصندوق وذللك بغرض در اسة تأثير تغييرمعدل سر عة الهواء على جودة ثمار الكانتالوب

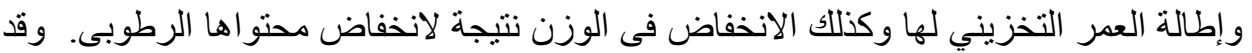

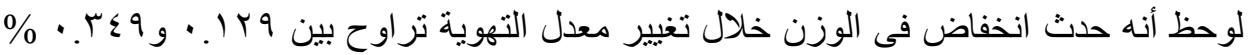

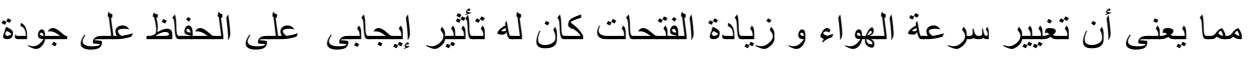

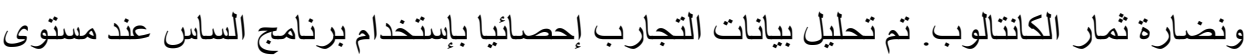
معنوية 0\% وكانت زيادة سر عة الهو اءو وزيادة نسبة الفتحات ذو معنوية عالية.

* مدرس بقسم الهندسة الزراعية والنظم الحيوية ـ كلية الزراعة - جامعة الاسكندرية - جمهورية مصر العربية. 